Proc. Estonian Acad. Sci. Eng., 2002, 8, 2, 114-120

\title{
Experimental investigation of the Saaremaa suspension bridge model
}

\author{
Valdek Kulbach and Egon Kivi \\ Department of Structural Design, Tallinn Technical University, Ehitajate tee 5, 19086 Tallinn, \\ Estonia; vkulbach@edu.ttu.ee \\ Received 8 February 2002, in revised form 1 April 2002

\begin{abstract}
A model of the bridge across the Suur Strait between the Estonian mainland and Muhu Island has been erected and tested. The main problem by designing of a self-anchored bridge is evaluation of the stability of the bended and compressed stiffening girder. In spite of a very slender box girder the approximate analysis and experimental investigation demonstrated its sufficient stability. The investigation proved also some advantages of the model with unloaded anchor cables as compared to the model with the loaded ones.
\end{abstract}

Key words: suspension bridge, cable structure, box girder, bridge model, girder stability, selfanchored system.

\section{INTRODUCTION}

Estonian greatest island Saaremaa is separated from the mainland by two straits with the Muhu Island between them. Overpass between the islands of Muhu and Saaremaa has existed in the form of an embankment for more than a hundred years. Thus, for the fixed link from the Estonian mainland to Saaremaa Island only an overpass from the mainland to Muhu Island is missing. The shortest southern trace crosses the strait over the northern coast of the islet of Viire. The whole length of the overpass (about $6100 \mathrm{~m}$ ) consists of a navigable span, two approach bridges with continuous girder structures, and two embankments $2100 \mathrm{~m}$ long in total. The total width of the bridge deck appointed by the Estonian Road Administration is $13 \mathrm{~m}$. It consists of two traffic lines of $3.75 \mathrm{~m}$ each and two safety strips of $2.75 \mathrm{~m}$. For the navigable span of the bridge, three structural models were under investigation: 1) a bowstring arch bridge with two slender arches and the tension member having considerable rigidity in bending, 2) a cable-stayed bridge with a composite girder, 3) a suspension bridge with a 
streamlined stiffening box girder. Due to comparatively deep foundation level of the anchor blocks, the construction of the latter would become too expensive; therefore a self-anchored suspension structure was preferred $\left[{ }^{1-3}\right]$. It requires only a moderate increase of the cross-sectional area of the stiffening girder that is much cheaper than construction of massive anchor blocks.

\section{DESCRIPTION OF THE MODEL}

The length of the middle span of the bridge was chosen $480 \mathrm{~m}$, and that of the side spans (projections of the length of anchor cables) $200 \mathrm{~m}$; the rise of the cables in the middle span was $60 \mathrm{~m}$. The rise of the cables for the side spans was determined from the condition of equality of the horizontal forces applied at the top of the pylon by the cables of the middle and the side spans. Schemes with unloaded as well as loaded side spans were investigated. Every cable for the original bridge consists of 37 ropes, each of a diameter of $52 \mathrm{~mm}$. Thus the diameter of the cable as a whole is $364 \mathrm{~mm}$, cross-sectional area $A=725 \mathrm{~cm}^{2}$, and the modulus of elasticity is $0.17 \times 10^{6} \mathrm{~N} / \mathrm{mm}^{2}$. The stiffening girder from steel has a box-formed cross-section with the upper plate $12 \mathrm{~mm}$ and the lower plate $6 \mathrm{~mm}$ thick, both having longitudinal trapezoidal stiffeners (Fig. 1). Depth of the box girder is $2.4 \mathrm{~m}$, total width $18 \mathrm{~m}$, cross-sectional area $8865 \mathrm{~cm}^{2}$, moment of inertia $I_{\mathrm{b}}=$ $0.5810 \mathrm{~m}^{4}$, and slenderness $\lambda=593$. Distance between the hangers is $24 \mathrm{~m}$. Nominal self-weight of the structure is $83.0 \mathrm{kN} / \mathrm{m}$, maximum traffic load $63.4 \mathrm{kN} / \mathrm{m}$ (with consideration of the lateral distribution of the load).

The model under investigation was erected in the scale of $1: 100$. The cables for the model had a diameter of $4.2 \mathrm{~mm}$, cross-sectional area $10.14 \mathrm{~mm}^{2}$, and modulus of elasticity $0.12 \times 10^{6} \mathrm{~N} / \mathrm{mm}^{2}$; rigidity in tension $E A=1.25 \times 10^{6} \mathrm{~N}$ corresponds well to the rigidity of the original $1.23 \times 10^{10} \mathrm{~N}$. In the model the stiffening girder was a timber board with the cross-section $180 \times 20 \mathrm{~mm}$. The cross-sectional area of the girder was $3600 \mathrm{~mm}^{2}$ and moment of inertia $120000 \mathrm{~mm}^{4}$; the rigidity in bending with normal value of the modulus of elasticity $10000 \mathrm{~N} / \mathrm{mm}^{2}$, equal to $0.120 \times 10^{10} \mathrm{~N} . \mathrm{mm}^{2}$, corresponds to the rigidity of the original $E_{\mathrm{b}} I_{\mathrm{b}}=$ $0.1220 \times 10^{18} \mathrm{~N} . \mathrm{mm}^{2}$. The hangers of the model had a spacing of $240 \mathrm{~mm}$, their lengths are determined by the parabolic form of the cable. The pylons of the model were made of tubular bars with a cross-section of $27 \times 2.5 \mathrm{~mm}$.

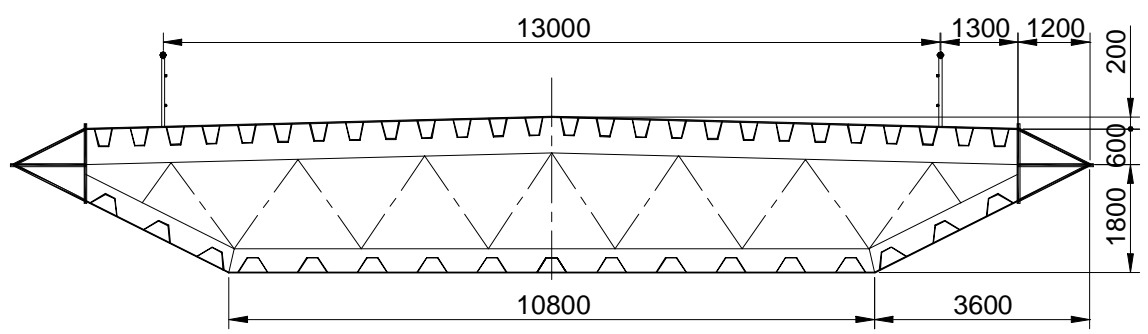

Fig. 1. Original structure: cross-section of the stiffening girder. 
The main goal of this investigation was evaluation of the stability of the bended and compressed slender stiffening girder and determination of the stressstrain state of the structure $\left.{ }^{4,5}\right]$. During experimental investigation of the bridge model the following measurements were carried out: 1) deflections of the structure under action of dead load and traffic loads, applied to the central span and to the half of it, to side spans, and to the whole length of the bridge; 2) horizontal displacements at the top of the pylons and at the anchoring nodes of the cables.

For obtaining reliable deflections, the metric rulers were used instead of special deflectometers. Horizontal displacements of the cable supporting nodes were measured with clock-type dial gauges.

\section{RESULTS OF THE TESTING AND COMPARISON WITH CALCULATED VALUES}

Vertical displacements of the structure were measured in the middle of the central and side spans and at quarters of the central span; displacements of the supporting nodes were also measured. The test load cases both for the model with loaded and unloaded anchor cables are shown in Table 1. The main part of the loads was applied by the weights of $26.5 \mathrm{~kg}$. Dead load corresponds to 3 weights per node (spacing $960 \mathrm{~mm}$ ). For modelling of the increased traffic load also 3 weights were used. Thus we had for every cable the dead load $p_{1}=0.415 \mathrm{kN} / \mathrm{m}$ and maximum traffic load $p_{2}=0.415 \mathrm{kN} / \mathrm{m}$. The initial load $p_{0}=0.135 \mathrm{kN} / \mathrm{m}$ was applied by smaller weights.

Table 1. Load cases

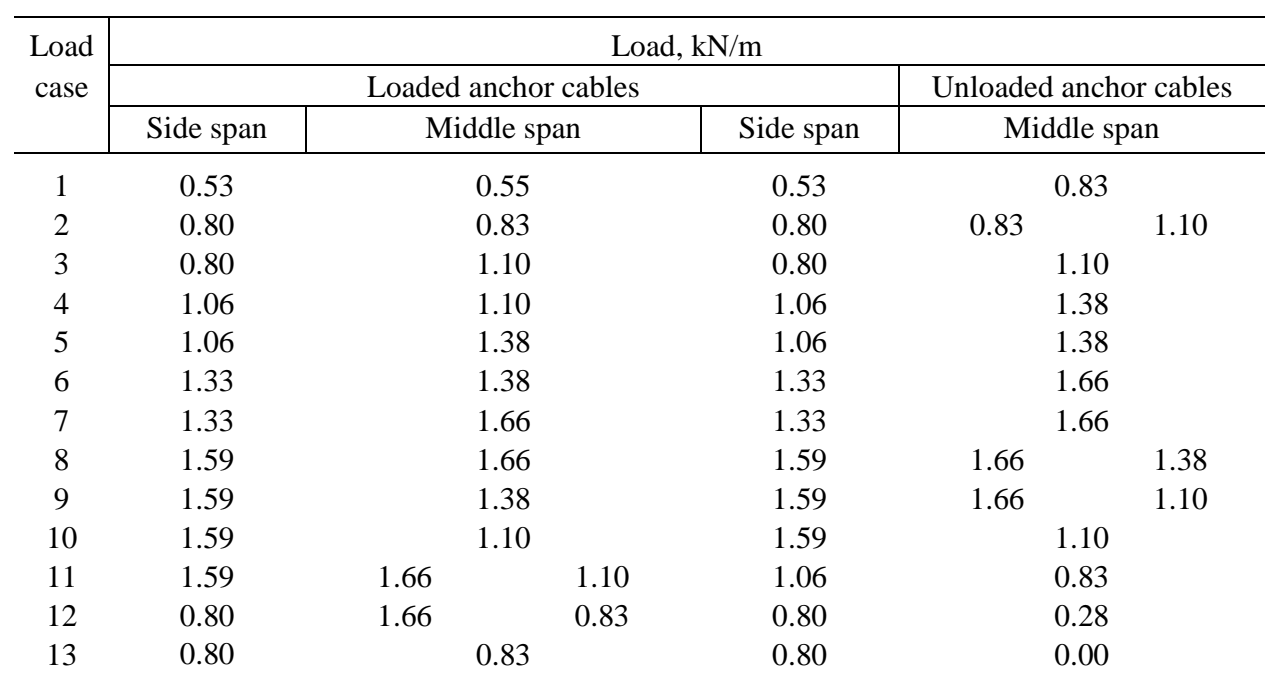


Vertical displacements of the model with loaded anchor cables for different load cases (Table 1) are presented in Fig. 2. Comparison of deflections in the middle and side spans is given in Fig. 3. For calculation, the equations of the continuous method $\left[^{6-8}\right]$ were used. In general, there is good agreement between the experimental and calculated values.
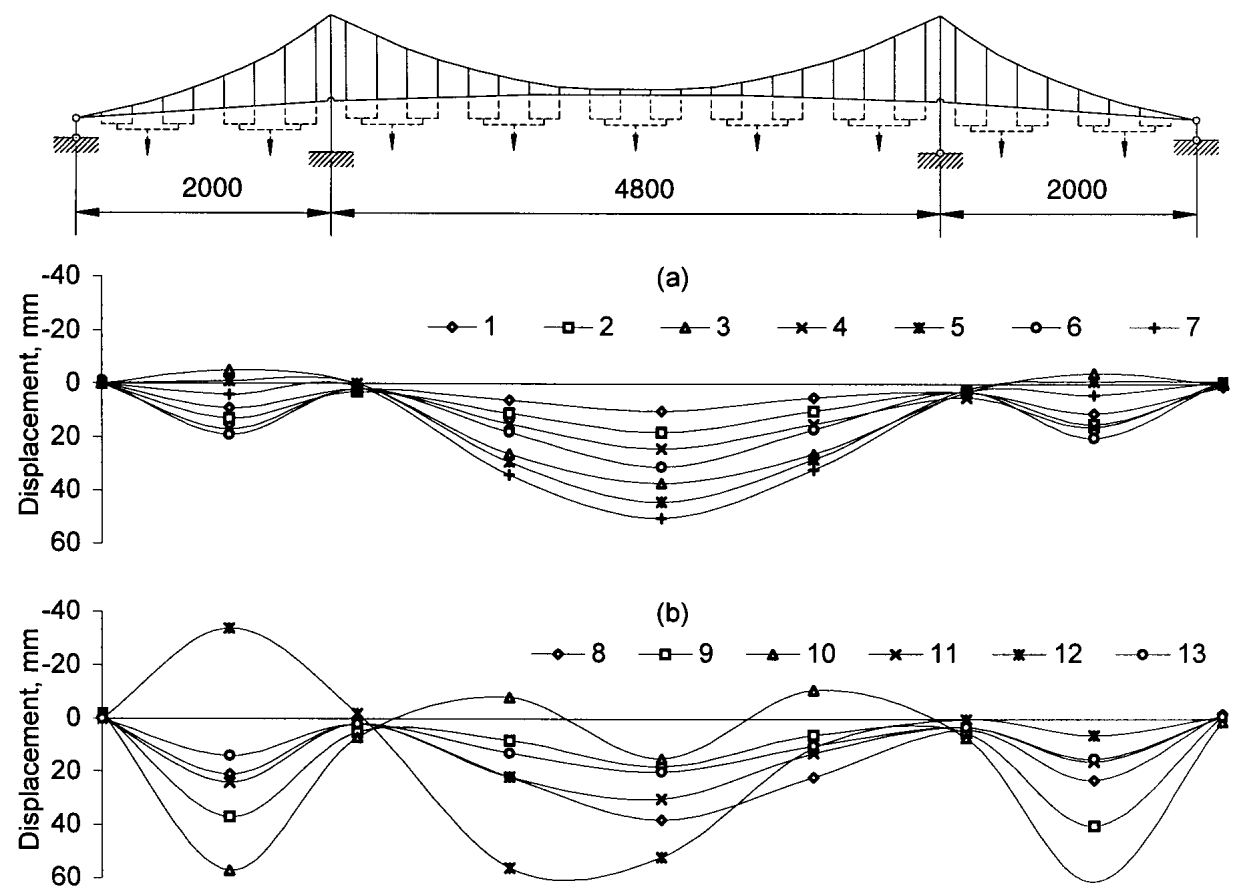

Fig. 2. Vertical displacements of the model with loaded anchor cables for load cases 1-7 (a) and 8-13 (b).

(a)

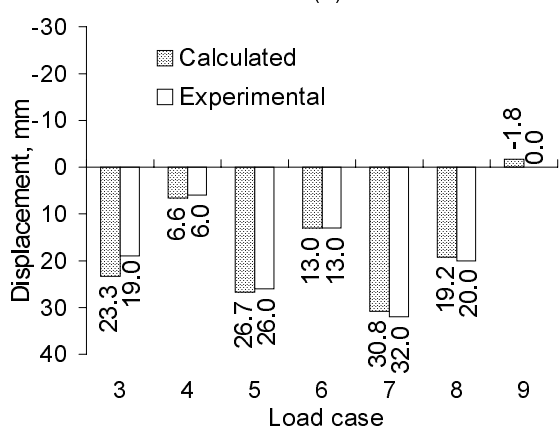

(b)

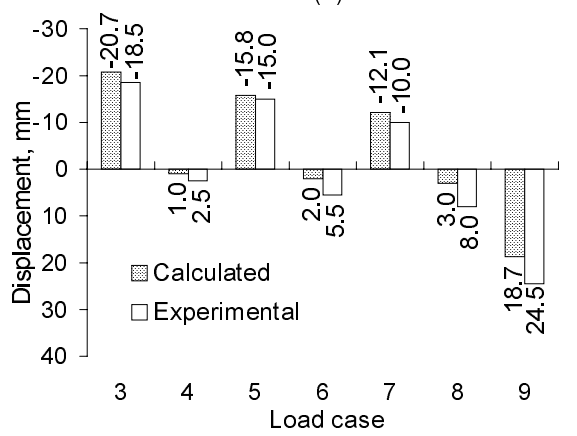

Fig. 3. Calculated and experimental displacements in the centre of the middle (a) and side (b) spans under the action of traffic load; the model with loaded anchor cables. 
Vertical displacements of the model with unloaded anchor cables are presented in Fig. 4. Comparison of the measured deflections in the middle span with the calculated ones is given in Fig. 5. Differences between the measured and calculated values up to $15 \%$ may be explained by the yielding of different fastenings, including deflections of the supporting nodes.
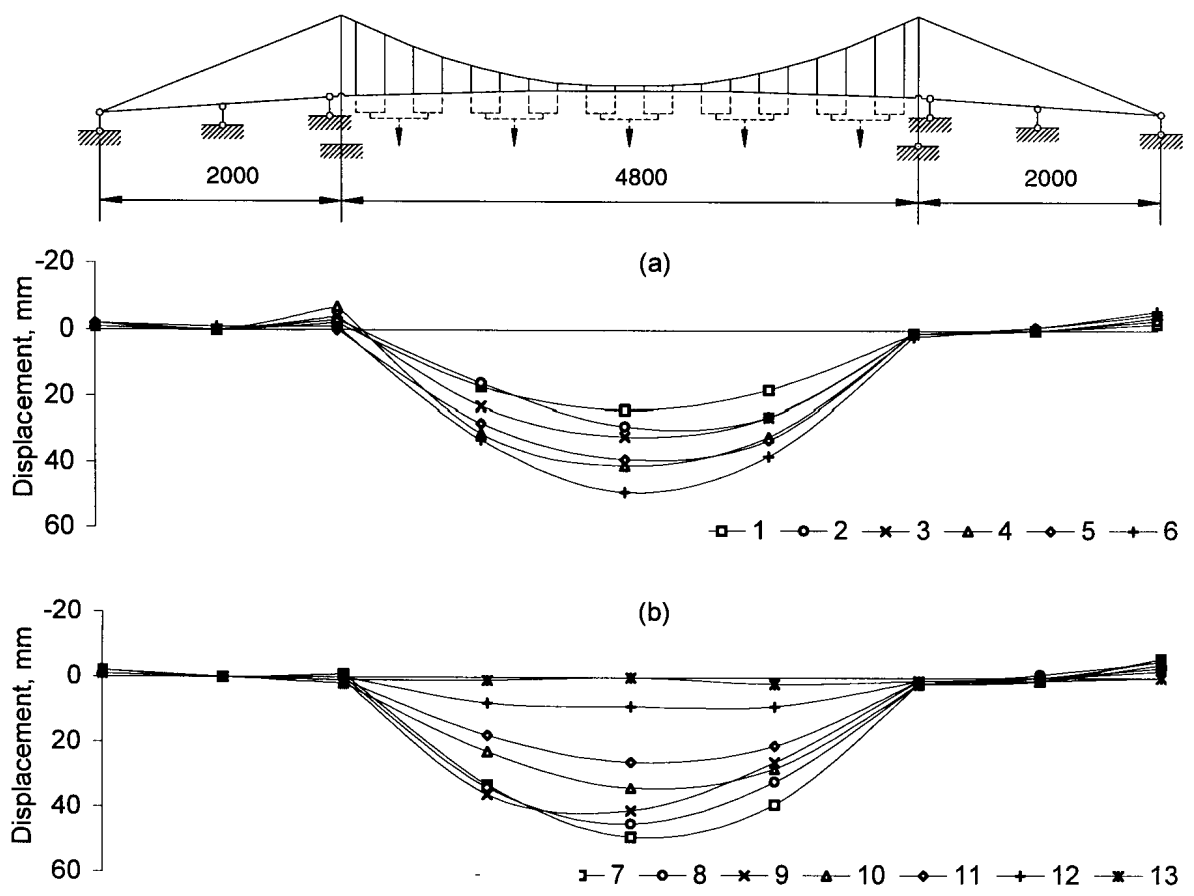

Fig. 4. Vertical displacements of the model with unloaded anchor cables for load cases 1-6 (a) and 7-13 (b).

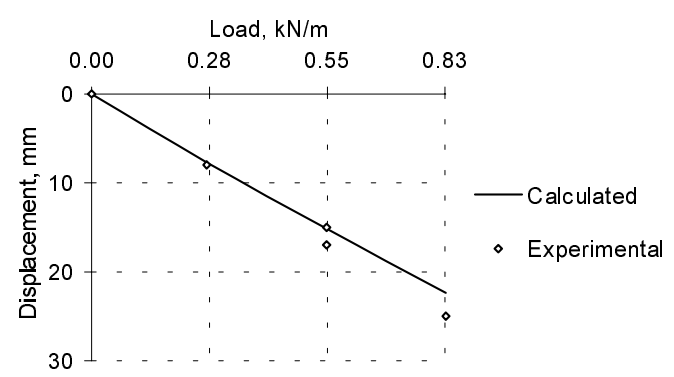

Fig. 5. Calculated and experimental displacements in the centre of the middle span under the action of traffic load; the model with unloaded anchor cables. 
Theoretical values of relative deflections of the structure with unloaded anchor cables were calculated from the cubic equation

$$
\zeta_{0}^{3}+3 \zeta_{0}^{2}+\left(2+\rho+p_{0}^{*}\right) \zeta_{0}=p^{*}
$$

where $\zeta_{0}=w_{0} / f$ is the relative deflection of the structure, $w_{0}$ is deflection in the middle of the span, $f$ is the cable sag,

$$
\begin{gathered}
p_{0}^{*}=H_{0} / \Phi, \quad p_{1}^{*}=P_{1} / \Phi, \quad P_{1}=p_{1} a^{2} / 2 f, \quad P_{2}=p_{2} a^{2} / 2 f, \\
\Phi=\frac{2 E A}{3 a^{2}(1+\kappa+\vartheta)}, \quad \kappa=2 \frac{f^{2}}{a^{2}}+1.2 \frac{f^{4}}{a^{4}}, \\
\vartheta=\frac{E A b}{E_{\mathrm{a}} A_{\mathrm{a}} a \cos ^{3} \beta}+\frac{E A(a+b)}{E_{\mathrm{b}} A_{\mathrm{b}} b}, \\
\rho=\frac{4 E_{\mathrm{b}} I_{\mathrm{b}}}{3 \Phi a^{2}},
\end{gathered}
$$

where $H_{0}$ is the prestressing force, $a=L / 2$ is half-span of the structure, $E A$ is rigidity of the cable in tension, $\kappa$ is sag factor of the cable, $\vartheta$ is the factor of support rigidity, $E_{\mathrm{a}} A_{\mathrm{a}}$ is rigidity of the anchor cable in tension, and $E_{\mathrm{b}} A_{\mathrm{b}}$ is the rigidity of the stiffening girder in tension.

The tested model was characterized by the following parameters: $a=2.4 \mathrm{~m}$, $f=0.592 \mathrm{~m}, \quad A=10.14 \mathrm{~mm}^{2}, \quad E=0.12 \times 10^{6} \mathrm{~N} / \mathrm{mm}^{2}, \quad \kappa=0.126, \quad \vartheta=1.104$, $\Phi=22.74 \mathrm{kN}, \quad H_{0}=0.657 \mathrm{kN}, \quad P_{1}=P_{2}=2.02 \mathrm{kN}, \quad p_{0}^{*}=0.0289, \quad p_{1}^{*}=p_{2}^{*}=$ $0.0888, \rho=0.0122$.

As a result of calculation we have for the load $p_{1}$ :

$$
\begin{gathered}
\zeta_{0}^{3}+3 \zeta_{0}^{2}+(2+0.0122+0.0289) \zeta_{0}=0.0888, \\
\zeta_{0}=0.0410, \quad w_{0}=24.3 \mathrm{~mm} .
\end{gathered}
$$

For the maximum load $p=p_{1}+p_{2}$ we have $p^{*}=0.1776, \quad \zeta_{0}=0.0779$, $w_{0}=46.1 \mathrm{~mm}$.

Comparison of the condition of stability of the stiffening girder for the actual bridge and the tested model can be done as follows. The ratio of the conventional critical forces may be estimated by comparison of the values of the critical force

$$
N_{\mathrm{cr}}=\pi^{2} E_{\mathrm{b}} I_{\mathrm{b}} / L^{2}
$$

For the actual bridge we have $N_{\mathrm{cr}}=\pi^{2} \times 0.1220 \times 10^{18} /\left(480^{2} \times 10^{6}\right)=$ $523 \times 10^{4} \mathrm{~N}$ and for the model $N_{\mathrm{cr}}=\pi^{2} \times 0.120 \times 10^{10} /\left(4.8^{2} \times 10^{6}\right)=514 \mathrm{~N}$. Taking into account the condition of similarity for the geometrical scale $1: 100$, we have an additional coefficient of safety 523/514 $=1.018$. 


\section{CONCLUSIONS}

1. Measured vertical displacements of the model are close to the calculated values.

2. Buckling of the stiffening girder does not occur in spite of its great slenderness and small rigidity in bending.

3. Experimental investigation of the models with unloaded and loaded cables of the side spans demonstrated notable advances of the first construction.

4. Analysis of the equations for the calculation of the deflections and results of experimental investigation confirm a relatively small influence of the rigidity of the stiffening girder on the deflections of the structure.

5. Results of this investigation confirm the suitability of a self-anchored suspension structure for the navigation part of the bridge to Saaremaa.

\section{REFERENCES}

1. Kulbach, V. and Talvik, I. Bridge structures for the fixed link Saaremaa. In Strait Crossings 2001 (Krokeborg, J., ed.). Lisse, The Netherlands, 2001, 221-226.

2. Ochsendorf, J. A. and Billington, D. P. Self-anchored suspension bridges. J. Bridge Eng., 1999, 4, 151-156.

3. Yoon, M.-G., Shin, H.-Y., and Son, Y.-S. The construction of the Youngjong Grand Bridge (selfanchored suspension bridge). In Cable-Supported Bridges - Challenging Technical Limits. IABSE Reports, Vol. 84, Seoul, 2001, 38-39.

4. Kulbach, V. and Talvik, I. Analysis of a self-anchored suspension bridge in Estonia. In CableSupported Bridges - Challenging Technical Limits. IABSE Reports, Vol. 84, Seoul, 2001, $170-171$.

5. Ermopoulus, J. Ch., Vlahinos, A. S., and Wang, Y.- C. Stability analysis of cable-stayed bridges. Comput. Struct., 1987, 44, 1083-1089.

6. Aare, J. and Kulbach, V. Accurate and approximate analysis of statical behaviour of suspension bridges. J. Struct. Mech. (Finland), 1984, 17(3), 1-12.

7. Kulbach, V. Statical analysis of girder- or cable-stiffened suspension structures. Proc. Estonian Acad. Sci. Eng., 1995, 1, 2-19.

8. Kulbach, V. Design of different suspension bridges. In Proc. Conference Eurosteel '99. CVUT, Prague, 1999, 395-398.

\section{Saaremaa rippsilla mudeli eksperimentaalne uurimine}

\section{Valdek Kulbach ja Egon Kivi}

On antud ülevaade Saaremaa rippsilla mudeli eksperimentaalsest uurimisest, mille puhul pöörati peatähelepanu jäikustala stabiilsusele. 